\title{
EFFECTS OF CITRUS ROOTSTOCKS ON SOME PLANT NUTRIENT ELEMENTS ABSORPTION OF GRAFTED CULTIVARS
}

\author{
V. RAMEEH ${ }^{1 *}$, M.R. RAMZANPOUR ${ }^{2}$, R. MATANI ${ }^{1}$ \\ *E-mail: vrameeh@gmail.com
}

Received: Dec. 13, 2019. Revised: Feb. 01, 2020. Accepted: Feb. 07, 2020. Published online: Mar. 06, 2020

\begin{abstract}
Citrus rootstocks have prime effects on the size of tree and fruit, quality of fruit and micorhyza dependence, which make difference in their leaf mineral elements concentration in leaf of grafted cultivars on them. A pot factorial experiment with two factors including rootstocks (sour orange, Citrange, Rough Lemon, Citrumelo and Yozo) and grafted cultivars (Thomson Navel, Sanguine, Unshiu Tangerine) was carried out in farm conditions with three replications. The studied traits were concentrations of elements in leaves including nitrogen, phosphorus, potassium, sulfur, magnesium, iron, manganese, zinc and copper. The result of analysis of variance revealed significant mean squares of variety, rootstock and their interaction effects for the elements in leaves. Citrumelo rootstock had mainly effect on nutritional elements in leaves. Unshiu mandarin with Citrumelo rootstock had the most amount of nitrogen and sanguine variety with Citrange
\end{abstract}

rootstock made the highest concentration of phosphorus and potassium in leaves of the grafted cultivar. Significant positive correlation of $\mathrm{K}$ with $\mathrm{Fe}$ and $\mathrm{Zn}$ indicating that all rootstocks with high mean value of $\mathrm{K}$ in leaf of grafted cultivar will have high amount of $\mathrm{Fe}$ and $\mathrm{Zn}$. Significant positive correlation also detected between $\mathrm{N}$ and $\mathrm{P}$ of leaf of grafted cultivars in combination with different rootstocks; therefore, most of combinations with high mean value of $\mathrm{N}$ had also high mean value of $P$. Unshiu Tangerine had high variation for $\mathrm{P}$, but Thomson Novel had lowest variation for this mineral element. Due to Significant positive correlation of $\mathrm{S}$ with $\mathrm{Mg}$ and $\mathrm{Mn}$, most of rootstocks with high amount of $\mathrm{S}$ in leaf of grafted cultivar had high mean values of $\mathrm{Mg}$ and $\mathrm{Mn}$ in their leaf of grafted cultivars.

Keywords: concentration; factorial experiment; fruit quality; leaf; vegetative growth.

\footnotetext{
${ }^{1}$ Agronomic and Horticulture Crops Research Department, Mazandaran Agricultural and Natural Resources Research and Education Center, AREEO, Sari, Iran

2 Soil and Water Research Department, Mazandaran Agricultural and Natural Resources Research and Education Center, AREEO, Sari, Iran
} 


\section{INTRODUCTION}

Citrus rootstocks differ in their degree of compatibility and adaptability to a grafted cultivar under a set of climate and soil conditions. Citrus rootstocks have also difference in root dispersion manner and micorhyza dependence, which make difference in their leaf mineral elements concentration or in leaf of grafted cultivars on them and finally affect vegetative growth and quantity and quality of the fruit (Tsakelidou et al., 2002; Bassal, 2009). Due to the benefits on solving the problems caused by soil, climates, pests and diseases, the rootstock exploitation is almost compulsory in citrus productions (Davies and Albrigo, 1998; Smith et al. 2004). The major rootstock of citrus in north province of Iran is sour orange (Citrus aurantium L.), whereas trifoliate (Poncirus trifoliate Raf.) and Troyer and Carrizo Citranges ( $P$. trifoliata Raf. $\times C$. sinensis Osb. var. "Troyer" and "Carrizo") are utilized as well. Although sour orange has many advantages over other rootstocks, its susceptibility to Tristeza virus have made researchers and producers to search for other alternatives (Davies and Albrigo, 1998; Georgiou and Gregoriou 1999; Obreza et al. 2002). The effects of rootstocks on several physiological and biochemical effects causing differences in plant development, productivity, fruit quality are well documented in several citrus species (Kaplankıran et al. 1999; Al-Jaleel and Zekri 2003; Perez-Zamora 2004).

Given that the rootstocks are diverse genotypes, they may influence the plant nutrient status of grafted cultivars grafted on them. These effects may even change on differential environments. For this reason, it is important to determine the effect of rootstocks on plant nutrient status to optimize fertilization programs. This may eventually be beneficial to optimize yield and quality in citrus orchards. In the grafted tree, rootstock type affects leaf mineral elements (Mattos Jr. et al., 2003; Toplu et al., 2008). Iqbal et al. (1999) reported that rootstock type has significant influence on mineral elements of Kinnow mandarin grafted cultivar leaf. Pestana et al. (2005) reported that Citrus rootstock significantly were different in iron absorption. Similar citrus, also in pistachio (Tavallali and Rahemi, 2007) and apple (Erdal et al., 2008) have been reported that rootstock type has significant influence on mineral elements concentration of grafted cultivar leaf. The objective of present study was to determine the rootstock effects on some plant nutrient element status of Thomson Navel, Sanguine, Unshiu Tangerine grafted on sour orange, Citrange, Rough Lemon, Citrumelo and Yozo.

\section{MATERIAL AND METHODS}

A pot experiment was conducted at Baykola Agriculture Research Station, located in Neka, Iran $\left(53^{\circ} 13^{\prime} \mathrm{E}\right.$ longitude and $36^{\circ} 43^{\prime} \mathrm{N}$ latitude, $15 \mathrm{~m}$ above sea 


\section{EFFECTS OF CITRUS ROOTSTOCKS ON GRAFTED CULTIVARS}

level) in farm conditions during 20042007. The experimental design was a completely randomized design (CRD) arranged in $5 \times 3$ (five root stocks and three grafted cultivars) factorial with three replications. Sour orange, Citrange, Rough Lemon, Citrumelo and Yozo were used as rootstocks and also grafted cultivars were Thomson Navel, Sanguine, Unshiu Tangerine. The studied traits were concentrations of elements in leaves including nitrogen $(\mathrm{N})$, phosphorus $(\mathrm{P})$, potassium $(\mathrm{K})$, sulfur $(\mathrm{S})$, magnesium $(\mathrm{Mg})$, iron $(\mathrm{Fe})$, manganese $(\mathrm{Mn})$, zinc $(\mathrm{Zn})$ and copper $(\mathrm{Cu})$ in leaf of grafted cultivars. Some climatically parameters of Baykola for 2006 and 2007 were as follows: averaged maximum temperature, 28.1 and $27.3^{\circ} \mathrm{C}$; averaged minimum temperature, 8.6 and $7.1^{\circ} \mathrm{C}$; averaged temperature, 19.1 and $18.8^{\circ} \mathrm{C}$, and aggregated precipitation, 676.8 and $685.1 \mathrm{~mm}$, respectively.

Soil analysis results are shown in Table 1. The soil belongs to the nonsaline soil with a natural reaction and the amount of lime, which is relatively high. Levels of nutrients, soil organic matter levels in the medium and other nutrients, including potassium, phosphorus, iron, manganese and copper are desirable. Seeds of related rootstocks were planted in the 3-liter pots in February 2004 and they were grafted with respected grafted cultivars in May 2006 and finally transferred to the 10-liter pots, which arranged factorial experiment. In each pot were added $60 \mathrm{mg} \mathrm{N} \mathrm{kg}^{-1}$ of soil as urea, $100 \mathrm{mg} \mathrm{K} \mathrm{kg}{ }^{-1}$ of soil as potassium sulfate, $15 \mathrm{mg} \mathrm{P} \mathrm{kg}^{-1}$ of soil as triple superphosphate, $15 \mathrm{mg} \mathrm{Mg} \mathrm{kg}^{-1}$ of soil as magnesium sulfate, $20 \mathrm{mg} \mathrm{Fe} \mathrm{kg}^{-1}$ of soil as ferrous sulfate, $20 \mathrm{mg} \mathrm{Zn} \mathrm{kg}^{-1}$ of soil as zinc sulfate, $20 \mathrm{mg} \mathrm{Mn} \mathrm{kg}{ }^{-1}$ of soil as manganese sulfate. Old leaves, 6-7 months, were sampled from the shoots in autumn in 2007 according to Chapman (1960).

Leaf samples were decontaminated by washing detergent solution, tap water and rinsing with distilled water. Leaflets were washed with mild detergent and then rinsed with distilled water, dried in a forced air drying oven at $70^{\circ} \mathrm{C}$ to constant weight. Leaf tissue was then ground to pass a 40 mesh screen. One gram of the dried leaf sample was turned to ash at $550^{\circ} \mathrm{C}$ for $5 \mathrm{~h}$. The ash was then dissolved in $5 \mathrm{ml}$ of $20 \% \mathrm{HCl}$. These samples were analyzed for $\mathrm{P}, \mathrm{K}, \mathrm{Mg} \mathrm{Ca}, \mathrm{Fe}, \mathrm{Zn}$ and $\mathrm{Cu}$ by atomic absorption spectrophotometer (Tandon, 1998). Total $\mathrm{N}$ was determined by a micro-Kjeldahl procedure (Lees, 1971).

Disease and pest control were made according to integrated pest management method. All the analyses were performed using MS-Excel and SAS software version 9 (SAS INSTITUTE INC, 2004).

Table 1 - Some of physicochemical properties of soil sample

\begin{tabular}{|c|c|c|c|c|c|c|c|c|c|c|c|c|c|}
\hline \multirow{2}{*}{ Class } & \multicolumn{3}{|c|}{$(\%)$} & \multicolumn{6}{|c|}{$\left(\mathrm{mg} \mathrm{kg}^{-1}\right)$} & \multirow{2}{*}{ TNV(\%) } & \multirow{2}{*}{$\mathrm{OC}(\%)$} & \multirow{2}{*}{ PH } & \multirow{2}{*}{$\begin{array}{c}E c \\
\left(\mathrm{dsm}^{-1}\right)\end{array}$} \\
\hline & Clay & Silt & Sand & $\mathrm{Cu}$ & $\mathrm{Zn}$ & Mn & $\mathrm{Fe}$ & $K$ & $\mathbf{P}$ & & & & \\
\hline Si-C-L & 28 & 56 & 16 & 3 & 0.64 & 3.1 & 9 & 352 & 9.2 & 15 & 1.41 & 7.3 & 0.68 \\
\hline
\end{tabular}

\section{RESULTS}

The result of analysis of variance revealed significant effects of grafted cultivars, rootstock and their interaction for macro elements, i.e. $\mathrm{N}$, $\mathrm{P}, \mathrm{K}$ and $\mathrm{S}$ and also micro elements, i.e. $\mathrm{Mg}, \mathrm{Fe}, \mathrm{Mn}, \mathrm{Zn}$ and $\mathrm{Cu}$ in leaves (Table 2). The highest $\mathrm{N}$ content $(3.24 \% \mathrm{DM})$ in leaf grafted cultivars 


\section{RAMEEH, M.R. RAMZANPOUR, R. MATANI}

was belonged to Sour orange rootstock. Sour orange, Citrange and Rough Lemon with 2.890, 2.967 and $2.867 \%$ DM in leaf of grafted cultivars were classified the same statistical group (Table 3). In viewpoint of $\mathrm{P}$ content, Citrange and Citrumelo with 0.21 and $0.19 \%$ DM in leaf of grafted cultivars had high mean value of this element. Citrange with $1.692 \%$ DM of $\mathrm{K}$ in leaf of grafted cultivars had the highest mean value of this macro element and the lowest mean value of $\mathrm{K}(1.303 \% \mathrm{DM})$ in leaf of grafted cultivars was belonged to Sour orange.

The high mean values of $\mathrm{S}$ in leaves of grafted cultivars exhibited in Citrumelo and Citrange and also these rootstocks made high mean value of $\operatorname{Mg}(0.213 \% \mathrm{DM})$ in leaves of grafted cultivars. Citrumelo and Rough Lemon with 183.30 and $154.7 \mathrm{ppm}$ of $\mathrm{Fe}$ in leaf of grafted cultivars had highest and lowest concentration of this element, respectively. Yozo had the highest mean value of $\mathrm{Mn}$ $(28.52 \mathrm{ppm})$ in leaf of grafted cultivars. Citrumelo and Sour orange with the 32.93 and $23.30 \mathrm{ppm}$ of $\mathrm{Zn}$ had the highest and lowest mean values of this micro element in leaf of grafted cultivars. Citrange and Yozo rootstocks with 26.85 and $21.72 \mathrm{ppm}$ of $\mathrm{Cu}$ had the highest and lowest mean values of $\mathrm{Cu}$ in leaf of grafted cultivars.

Cultivars had different efficiency for macro and micro elements absorption (Table 4). Unahiu Tangerin and Thomson Novel with 3.022 and $2.830 \% \mathrm{DM}$ in leaf had highest and lowest mean values of $\mathrm{N}$ on all rootstocks. Cultivars had not prime significant for $\mathrm{P}$ absorption. Thomson Novel with $1.641 \%$ DM of K in leaf had highest efficiency for this macro element absorption. Thomson Novel and Sanguine with the high mean values of $\mathrm{S}$ and $\mathrm{Mg}$ in leaf were classified the same statistical group and Unahiu Tangerin had the lowest mean values of these mineral elements. Thomson Novel had also the highest amount of $\mathrm{Fe}$ and $\mathrm{Mn}$ (187.3 and $25.56 \mathrm{ppm}$, respectively) and the lowest mean values of $\mathrm{Fe}$ and Mn was devoted to Unahiu Tangerin. The highest mean values of $\mathrm{Zn}$ and $\mathrm{Cu}$ belonged to Sanguine and Unahiu Tangerin, respectively, and the lowest amounts of these micro elements were related to Unahiu Tangerin and Thomson Novel, respectively.

Significant mean squares of grafted cultivars (cultivars) and rootstocks interaction effects for macro and micro elements in leaves indicated that the trends variation of mineral elements in grafted cultivars were different in different rootstocks. Thomson Novel on rootstock of Citrange and Sanguine on Sour orange and highest amount Citrange had high mean values of $\mathrm{N}$, but Unshiu Tangerine on Rough Lemon and Citrumelo had high amounts of $\mathrm{N}$ (Table 5). Correlation between each two mineral elements in combinations of three grafted cultivars and five rootstocks are shown in Table 6 . About $20 \%$ of correlations between the mineral elements were significant. 


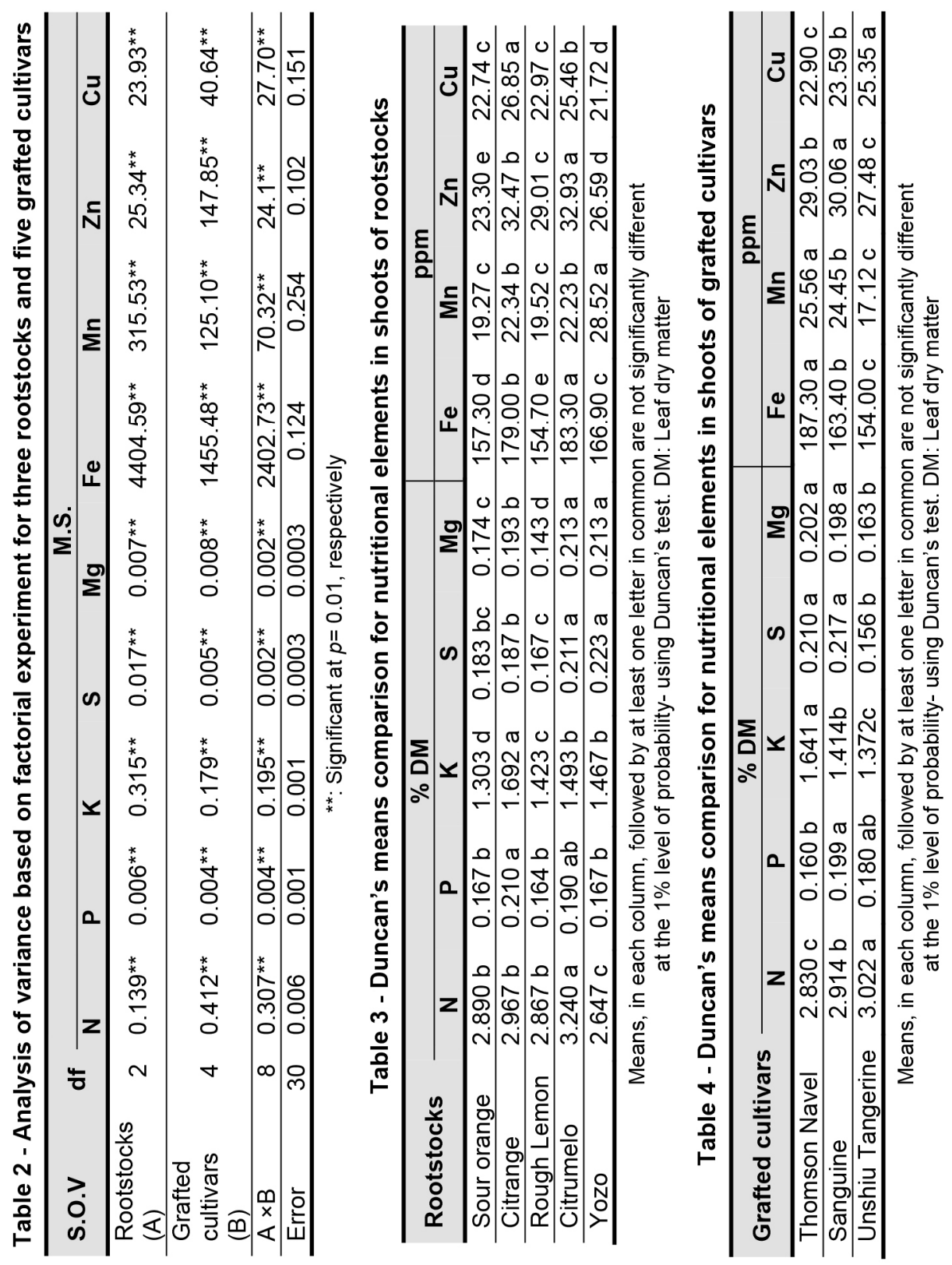




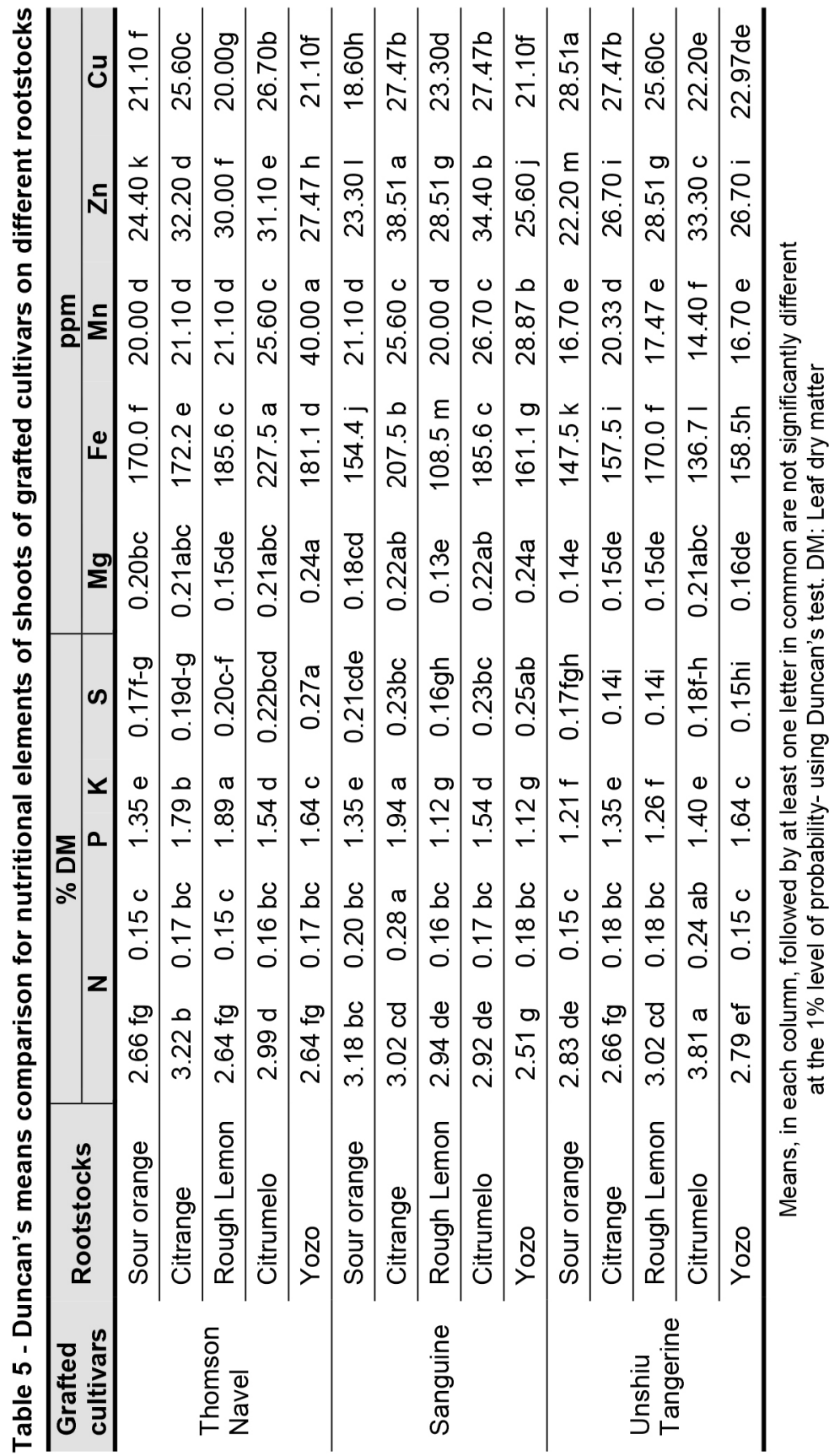




\section{EFFECTS OF CITRUS ROOTSTOCKS ON GRAFTED CULTIVARS}

Table 6 - Correlation among the mineral elements in combinations of grafted cultivars and five rootstocks

\begin{tabular}{|c|c|c|c|c|c|c|c|c|c|}
\hline & $\mathbf{N}$ & $\mathbf{P}$ & K & S & Mg & $\mathrm{Fe}$ & Mn & $\mathrm{Zn}$ & $\mathrm{Cu}$ \\
\hline $\mathrm{N}$ & 1 & & & & & & & & \\
\hline$P$ & $0.54^{*}$ & 1 & & & & & & & \\
\hline $\mathrm{K}$ & 0.06 & 0.25 & 1 & & & & & & \\
\hline S & -0.15 & 0.23 & 0.31 & 1 & & & & & \\
\hline $\mathrm{Mg}$ & 0.07 & 0.37 & 0.28 & $0.81^{* *}$ & 1 & & & & \\
\hline $\mathrm{Fe}$ & -0.18 & 0.12 & $0.63^{*}$ & 0.49 & 0.49 & 1 & & & \\
\hline $\mathrm{Mn}$ & -0.44 & 0.01 & 0.23 & $0.85^{\star *}$ & $0.66^{* *}$ & 0.45 & 1 & & \\
\hline $\mathrm{Zn}$ & 0.43 & $0.60^{*}$ & $0.62^{*}$ & 0.26 & 0.39 & 0.44 & 0.13 & 1 & \\
\hline $\mathrm{Cu}$ & 0.06 & 0.10 & 0.06 & 0.22 & -0.12 & 0.26 & -0.13 & 0.36 & 1 \\
\hline
\end{tabular}

\section{DISCUSSION}

Rootstocks had significant effects on macro and micro elements concentrations in leaf of grafted cultivars. Citrumelo rootstock had first to second rank for most of macro and micro elements. Some researchers (lqbal et al., 1999; Georgiou, 2002, Mattos Jr., et al., 2003; Toplu et al., 2008; Bassal 2009) also have been emphasized the influence of rootstock type on mineral element concentration of grafted cultivar leaf in different grafted cultivar and rootstock combinations. Significant positive correlation detected between $\mathrm{N}$ and $\mathrm{P}$ of leaf of grafted cultivars in combination with different rootstocks; therefore, most of combinations with high mean value of $\mathrm{N}$ had also high mean value of $P$. Unshiu Tangerine had high variation for $\mathrm{P}$, but Thomson Novel had lowest variation for this mineral element.

The highest mean value of $P(0.28 \%$ DM in leaf) in Sanguine which grafted on Citrange, but the highest value of this element in
Unshiu Tangerine detected on rootstock of Citrumelo. Although variation of $\mathrm{K}$ in leaf of grafted cultivars on different rootstocks was low, but ranks of grafted cultivars were different in combination to five rootstocks. The highest concentration of $\mathrm{K}$ was determined in Thomson Novel with combination of Rough Lemon and its lowest mean value belonged to Sanguine to combination of rootstocks of Rough Lemon and Yozo. Due to importance $\mathrm{K}$ for tolerance to stress conditions, Rough Lemon rootstock can be preferred than other rootstocks for limitation of K. Significant positive correlation of $\mathrm{K}$ with $\mathrm{Fe}$ and $\mathrm{Zn}$ indicating that all rootstocks with high mean value of $\mathrm{K}$ in leaf of grafted cultivar will have high mean values of $\mathrm{Fe}$ and $\mathrm{Zn}$. The highest amount of $S$ detected in Thomson Novel on Yozo and its lowest mean value also exhibited in Unshiu Tangerine for rootstocks of Citrange and Rough Lemon. Due to significant positive correlation of $\mathrm{S}$ with $\mathrm{Mg}$ and $\mathrm{Mn}$, most of rootstocks with high amount of $\mathrm{S}$ in leaf of 
grafted cultivar had high mean values of $\mathrm{Mg}$ and $\mathrm{Mn}$ in their leaf of grafted cultivars. Rough Lemon and Citrange made low and high mean values of $\mathrm{Mg}$ in all of cultivars, respectively.

Georgiou (2002), in evaluation of mineral elements of Clementine mandarin's leaf on 12 rootstocks, reported that there was significant difference between rootstocks in viewpoint of $\mathrm{Mg}, \mathrm{Cu}$ and $\mathrm{B}$ concentrations in grafted cultivar leaf. Thomson Novel had high relatively of $\mathrm{Fe}$ on all of rootstocks and its highest mean value was resulted on Citrumelo rootstock and the cultivar Unshiu Tangerine had low mean value of $\mathrm{Fe}$ on all rootstocks. $\mathrm{Mg}$ and $\mathrm{Mn}$ had the same trend variation in grafted cultivars of most studied rootstock. The highest amount of Mn detected in Thomson Novel on Yozo and its lowest mean value also determined in Unshiu Tangerine on rootstocks of Citrumelo. Sanguine had high mean value of $\mathrm{Zn}$ (38.51 ppm of $\mathrm{Zn}$ in leaf) on Citrange rootstock and the lowest mean value of this micro element was detected in Unshiu Tangerine on Sour orange rootstock. All cultivars had high mean values of $\mathrm{Cu}$ on Citrange rootstock. Difference macro and micro elements contents of grafted cultivar leaves are depending on ability of different rootstocks to absorption and sending of mineral elements to shoot. This subject also has been reported by other researchers in other grafted cultivar and rootstock combinations (Iqbal et al., 1999; Georgiou, 2002; Mattos Jr. et al., 2003; Toplu et al., 2008; Bassal, 2009).

\section{CONCLUSIONS}

Due to significant interaction effects of rootstocks and grafted cultivars, the rank of cultivars for mineral elements absorption were different.

Significant positive correlation of $\mathrm{K}$ with $\mathrm{Fe}$ and $\mathrm{Zn}$ indicating that all the rootstocks with high mean value of $\mathrm{K}$ in leaf of grafted cultivar will have high amount of $\mathrm{Fe}$ and $\mathrm{Zn} . \mathrm{Mg}$ and $\mathrm{Mn}$ had the same trend variation in grafted cultivars of most studied rootstock, therefore selection a special rootstock and grafted cultivar with high mean value of $\mathrm{Mg}$ will result of high amount of Mn.

\section{REFERENCES}

Al-Jaleel, A. \& Zekri, M. (2003). Effect of rootstocks on yield and fruit quality of 'Parent Washington Navel' trees. Proc.Fla. State Hort.Soc., 116: 270275.

Bassal, M.A. (2009). Growth, yield and fruit quality of "Marisol" clementine grown on four rootstocks in Egypt. Sci.Hortic., 119(2): 132-137, DOI: 10.1016/j.scienta.2008.07.020

Chapman, H.D. (1960). Leaf and soil analysis in citrus orchards, criteria and diagnosis of management practice. Manuel Berkeley, California: University of California Division of Agricultural Science, p. 25.

Davies, F.S. \& Albrigo, L.G. (1998). Citrus. $\mathrm{CAB}$ International, Wallingford, UK.

Erdal, I., Askin, M.A., Kucukyumuk, Z., Yildirim, F. \& Yildirim, A. (2008). Rootstock has an important role on iron nutrition of apple trees. World J.Agric.Sci., 4(2): 173-177. 


\section{EFFECTS OF CITRUS ROOTSTOCKS ON GRAFTED CULTIVARS}

Georgiou, A. (2002). Evaluation of rootstocks for 'Clementine' mandarin in Cyprus. Sci.Hortic., 93(1): 29-38, DOI: $\quad 10.1016 / S 0304-4238(01) 003$ 11-9

Georgiou, A. \& Gregoriou, C. (1999). Growth, yield and fruit quality of 'Shamouti' orange on fourteen rootstocks in Cyprus. Sci.Hortic., 80(1-2): 113-121, DOI: 10.1016/S0 304-4238(98)00232-5

Iqbal, S., Chaudhray, M.I. \& Anjum, M.A. (1999). Effect of various rootstocks on leaf mineral composition and productivity of Kinnow mandarin. Int.J.Agric.Biol., 1(3): 91-93.

Kaplankıran, M., Demirkeser, T.H., Toplu, C., Ülbeği, E. \& Uysal, M. (1999). The effect of rootstocksscion combination plants nutrient element contents of leaves in Valencia oranges. III. Turk.Natl.Hortic.Congr., 1: 93-97.

Lees, R. (1971). Laboratory handbook of methods of food analysis. Leonard Hill Boks, London.

Mattos Jr., D.., Quaggio, J.A., Cantarella, H. \& Alva, A.K. (2003). Nutrient content of biomass components of Hamlin sweet orange trees. Sci.Agric., 60(1): 155-160, DOI: $10.1590 / S 0103-901620030001$ 00023

Obreza, T.A., Alva, A.K., Hanlon, E.A. \& Rouse, R.E. (2002). Citrus grove leaf tissue and soil testing: sampling, analysis and interpretation. University of Florida. Cooperative Extension Service. Inst. Food Agric. Sci.

Pérez-Zamora, O. (2004). Leaf nutrient concentration, yield, production efficiency, juice quality and nutrimental indexes on Valencia orange grafted on citrus rootstocks. Agrociencia, 38(2): 141-154.
Pestana, M., de Varennes, A., Abadía, J. \& Faria, E.A. (2005). Differential tolerance to iron deficiency of citrus rootstocks grown in nutrient solution. Sci.Hortic., 104: 25-36, DOI: 10.10 16/j.scienta.2004.07.007

SAS INSTITUTE INC. (2004). SAS/STAT user's guide. Version 9, 5th Edition. Statistical Analysis Institute Inc., Cary North Carolina.

Smith, M.W., Shaw, R.G., Chapman, J.C., Owen-Turner, J., Lee, L.S., McRae, K.B., Jorgensen, K.R. \& Mungomery, W.V. (2004). Longterm performance of 'Ellendale' mandarin on seven commercial rootstocks in subtropical Australia. Sci.Hortic., 102(1): 75-89, DOI: 10.1016/j.scienta.2003.12.004

Tandon, H.L.S. (ed.) (1998). Methods of analysis of soil, plants, waters and fertilizers. Fertilizer Development and Consultation Organisation 204204A Bhanot Corner, 1-2 Pamposh Enclave, New Delhi, 10048

Tavallali, V. \& Rahemi, M. (2007). Effect of rootstock on nutrient acquisition by leaf, kernel and quality of pistachio (Pistacia vera L.). American-Eurasian J.Agric.Env.Sci., 2(3): 240-246.

Toplu, C., Kaplankiran, M., Demirkeser, T.H. \& Yildiz, E. (2008). The effects of citrus rootstocks on Valencia late and rhode Red Valencia oranges for some plant nutrient elements. Afr.J.Biotechnol., 7(24): 4441-4445.

Tsakelidou, K., Papanikolaou, X. \& Protopapadakis, E. (2002). Rootstock effects on the yields, tree and fruit characteristics of the mandarin cultivar 'Clementine' on the Island of Rhodes. Exp.Agric., 38(3): 351-358, DOI: 10.1017/S001 4479702003071. 